\title{
Raymond Williams and the Politics of the Commons: The Performative Quality of the Intellectual.
}

Much of the sociological work on intellectuals is mostly concerned with the structural role they play within society. In this respect, Raymond Williams is best understood in Gramscian (1988) terms as an organic intellectual connected to the labour movement and the working-class, seeking to criticise the dominating features of contemporary capitalism. Williams is widely seen as a post-war intellectual connected to the New Left and organised labour. Indeed Williams's (1981) own account of intellectuals is mostly concerned with exploring the structurally conditioned class-based society disallows critical study. More recently sociological work has concentrated on the reasons behind the relative decline of intellectuals due to the dominance of think tanks, consumerism and the increasingly instrumental narrow specialisms (Furedi 2004, Misztal 2012). There is then perhaps a nostalgia for the 'big intellectuals' of the past who were capable of producing intellectual narratives beyond the more modest aims of contemporary knowledge producers (Bauman 1992). Whatever the contemporary insights of this view, there are limitations to the sociologicallyinformed, structural account of intellectual cultural production. Jeffrey Alexander (2016) has recently argued that the sociology of intellectuals needs to take a more performative turn. Instead of viewing intellectuals purely in terms of structural class relationships we need to understand their ability to produce dramatic and compelling narratives. In other words, when considering intellectuals we need to understand their ability to create exciting stories and compelling performances. Especially significant in this respect are heroic narratives and the stories of good versus evil. In other words, the performative effect of ideas is in making an impact upon society. As a Durkheimian sociologist Alexander (2016:348) is interested in how intellectuals produce ideas of the sacred and profane through the production of binary categories more generally. However Alexander (2003:228) also argues that investigating the ways in which moral categories become constructed through codes and narratives is especially important in the current setting. For example, the work by Marxist intellectuals in the past reproduced binary categories they claimed would eventually lead to the salvation of humanity. Here Alexander (2003:228) is suggesting we need to respect the power of the stories produced by intellectuals, but at the same time be cautious of their 'totalizing conceit'. In other words, we need to recognise the reductive nature of many of these stories. Here I want to argue that Alexander's work on intellectuals offers new possibilities for the study of intellectuals like Raymond Williams, but is sometimes (although not always) a problematic guide to the complexity of Marxist writing. As Baert and Morgan (2017:5) argue, an emphasis upon performativity can overwhelm the need to make connections between dramatised and more structural accounts. In this respect, I shall argue that beyond the performative dimensions of Williams's writing there remain good reasons to return to his work not only within our shared neoliberal times, but in the context of the rise of radical social movements against austerity seeking to defend the commons. 


\section{Williams, Marxism and Performativity}

The idea that our shared values, cultures and meanings are under attack by the economy is hardly new and can be traced back to the Romantic movement of the eighteenth century. While this tradition has many problematic features it continues to be the basis of much social and cultural critique that is concerned about the shared quality of our lives (Williams 1958). The humanist emphasis of the commons offers a radical critique of other intellectual movements like postmodernism and cosmopolitanism for not squarely facing the threat that is being posed by neoliberal capitalism. Here I seek to focus upon the contribution of Raymond Williams to the idea of the art of the commons. Williams as a member of the post-war New Left did not explicitly seek to address the idea of the commons and yet his work has a number of important implications as to how we might understand this idea after his death in 1988. While our own times are different from those in which Williams wrote, given the intensification of the neoliberal project and the partial erasure of the radical working-class movement his ideas remain worth revisiting in the current climate.

In addition, I also wish to recover what we might call the performative quality of Williams's writing and intellectual positions. If intellectuals remain significant mostly in terms of their arguments we should also consider how and why they continue to have a resonance within our culture (Baert 2015). Raymond Williams was not an especially charismatic speaker and had little interest in becoming a celebrity academic. He did not regularly appear on television and was not a well-known personality, and yet academic conferences are still held in his name and he has been the subject of numerous academic studies. A clue to Williams's resonance as a thinker is offered by Marxist historian Perry Anderson. Anderson's (1976) widely read account of Western Marxism is understood as a definitive text in the canon. Anderson argues that for all the theoretical complexity of the Western Marxist tradition it had mostly failed to find a resonance amongst the working-class movement. The two possible exceptions to this argument were Antonio Gramsci and Raymond Williams. In Williams's case Anderson (1976:105) describes him as a 'distinguished socialist thinker' whose significance lay in his ability to connect his own experience and class history to the need to produce socialist ideas. It is Williams's own location within the working-class that offers his work an 'authenticity' missing from other New Left intellectuals of the period. In this respect, the performative quality of Williams's work could be said to have a number of sources. The first comes from his association with Marxism. Williams became increasingly interested in the work of Marx and Marxism as he sought to develop his own distinctive critique of the capitalist system. If, after the revolutions of 1989, these positions became deeply unfashionable as much of academic debate turned away from Marxism in the wake of the collapse of Eastern European state socialism then today we occupy a different intellectual moment. After the financial crash of 2008 many of the questions asked by Williams have taken on a new resonance. The capacity of neoliberal capitalism to produce a humane and sustainable social citizenship suitable for the twenty-first century, along with the rise of social movements against austerity and the anti-globalisation movement opens out a different set of questions. As Williams and much of the New Left argued the emergence of a more democratic Marxism, as opposed to the heritage of MarxismLeninism, requires a considerable amount of rethinking in the future. If Marxism can be said to continue to 'haunt' our culture it does so because of the continued failure of 
capitalist globalisation to provide a civilisation fit for the future of humanity. Here we need to be reminded of the stubbornness of Marxism in its refusal to accept that capitalist modernity and neoliberalism will ever produce a society other than that based upon huge social and economic inequalities and the dominance of instrumental forms of rationality that are hostile to questions of cultural value. The other source of Williams's 'authenticity' lies with his ability to both act as a 'committed' intellectual while exploring his working-class background. Many of Williams's novels and much of his autobiographical writing explores the complexity of working-class experience in seeking to survive the effects of an exploitative economic system. It is however not only Williams's own 'lived' connection to the working-class that continues to give his work a sense of authenticity, but also the way his writing produces a sense of working class subjectivity. Here Williams's writing continues to exhibit a family resemblance to other socialist realist 'fictions' like those produced by film maker Ken Loach. Ken Loach's most recent film 'I, Daniel Blake' seeks to dramatise the plight of many working-class people who are forced to rely upon a bureaucratic and indifferent welfare-benefits system. The film mostly works through an opposition between the corruptions of capitalism and hierarchy and the often hidden humanity of poor working-class people. Similarly many of Williams's (1988a) best novels like Border Country reveal a defiant working-class humanity that opposes capitalism while seeking to develop a sense of mutual aid, respect and solidarity with one another. Here I seek to recognise this opposition as both too simple while remaining an extraordinary powerful cultural resource in the struggle for a world less driven by the practices of capitalism. As Jeffrey Alexander (2011) argues, in seeking to understand the performative and affective dimensions of different political positions and arguments we need to examine the ways that they resonate (or indeed otherwise) with the lives of ordinary citizens. Paradoxically while Williams might seem to be an antiperformative intellectual, his connection to the organised working class gives his work a considerable amount of 'authenticity' in a number of critical debates that had until recently neglected to analyse the centrality of the dominant capitalist and class society. Finally the critical educationalist Henry Giroux (2011) argues that critical intellectuals such as Williams exhibit a distinctive kind of performativity in how they refuse simply to retreat into the text, but seek to create the conditions for a more contested view of power and resources while actively intervening in public disputes and conflicts. Williams produced many challenging theoretical texts and also sought to act as a critical public intellectual seeking to translate knowledge into political practice. He was able to do this by writing in such a way whereby he was able to close the gap between troubling public questions and carefully defined public interventions. Williams does this not only through his long term defence of socialist ideas, but also by consciously positioning himself as someone writing from the point of view of the labour movement. Williams's writing in this sense is performative for its ability to reignite a concern for the distribution of power and wealth within society and for his commitment to a genuinely democratic politics that needs to be struggled for in the context of the on-going domination of capitalism. Here Williams rejects the idea of the academic as a neutral commentator in favour of someone who seeks to disrupt and question the normalisation of capitalism under neoliberalism. By refusing the myth of the intellectual disconnected from the power structure of society, Williams's writing remains performative in that he deliberately connects his writing to the radical labour movement and the need to argue for a humane alternative to the barbarism of capitalism. Not surprisingly, after the market crash of 2008 there has been a widely recognised need to recover more critical accounts of capitalism that were previously 
displaced by sociology. Williams's work is likely to remain central to this endeavour not only for its ability to produce a compelling narratives about questions of class, but also for its ability to connect to the horizons of the recently emerged alterglobalisation movement and movements against austerity. Here I shall explore these features further.

\section{Capitalism and the Commons}

The increasing commodification of art, nature and shared public goods threatens to convert all that we share into new initiatives to make money. As the historian Peter Linebaugh (2014) has argued 'commoning' is a practice that places human solidarity at the heart of our imagination and depends upon what we all own collectively. Capitalism depends upon hierarchical control from above and practices of commodification; the commons is connected more intimately with self-management, democracy and cultures in common. If neoliberalism is seen to embody common sense ideas such as competition, selfishness and accumulation then the idea of the commons inevitably points to other human possibilities and qualities beyond the naturalisation of narrow individualism. The writer and activist David Bollier (2014:37) similarly argues that the politics of the commons is the attempt to resist 'the dispossession of commoners as market forces seize control of common resources'. Ultimately this process ends by creating a 'monoculture' or the homogenous culture of the market, whereby access to culture, nature and other goods previously held in common becomes more hierarchical and restricted. The assault on public libraries, the internet, the environment and access to the arts all come under threat within the context of state-endorsed neoliberalism from above.

David Harvey (2012) argues that the history of capitalism has long been implicated in a struggle between genuinely public spaces that are held in common and the logic of capitalism and commodification. In the age of global capitalism the superrich increasingly depend upon private health care, gated communities, exclusive schools and of course an ability to influence the shape of state policy that is mostly denied to ordinary citizens. In this respect, as Terry Eagleton (2011:167) puts it, class structure is 'the joker in the pack of civilisation'. This is because, despite the claims that class struggle is a thing of the past, there is an ongoing inequality at the heart of the system in terms of who gains access to the profits produced by capitalism, and whose priorities, values and practices get to shape our shared institutions and cultures.

Within this setting the relentless logic of privatisation and commodification has sought to exclude questions of the common good and has transferred wealth, power and control into the hands of the few rather than the many. As Raymond Williams (1983) recognises, capitalism is a social system based upon inequalities of ownership and control, where knowledge and relationships are built upon domination more generally. This means that capitalism is intrinsically hostile to the 'general interest', given that it is based upon class exploitation (Williams 1983: 163). For Williams and other members of the New Left the considerable achievements of social democratic citizenship could never be considered permanent, given capitalism's hostility towards attempts to foster deeper forms of democracy and security within the citizenry. In addition, the more democratically-orientated communities of the future would need to break with the assumption evident within capitalism and more elitist modes of thought that viewed the vast majority of people in homogenous terms 
(Williams 1958). More democratic ways of life depend upon the principle of equality and humanistic values that seek less to impress inequality, upward mobility and competition than the principles of human solidarity and communication. The idea of the commons in Williams's assessment was linked to notions of the common interest, as opposed to the private interests of capitalism, but equally it was connected to the need to rethink the relationships between the country and the city. The recovery of the commons would need to break with the 'insane overconfidence in the specialised powers of metropolitan industrialism' that threatens 'human survival' (Williams 1989a: 84). For Williams (1980a:269) a cultural revolution was required to challenge the priorities of the instrumental capitalist order. This would inevitably mean that socialists would devise alternative plans that not only sought to redistribute wealth, but also significantly to decentralise power and control. Within this process what became pressing was developing an increasingly 'materialist' analysis of both the human and ecological costs of capitalism. This would mean addressing the central logic of consumerism that sought to suggest that products have 'magical' qualities. Instead a genuine democracy of the commons 'is not a system of government but of self-government' that was 'rooted in the satisfaction of human needs and the development of human capacities' (Williams 1980b:185).

Williams persistently argued that a democratic revolution developing through the labour movement and the gradual reform of representative institutions was possible and necessary. Williams was well aware, especially since the turn to the political Right in the 1980s, that alternatives would need to be considered in the future. As the commons activist David Bollier (2014) has argued, rather than relying upon the market and the state to reshape our society in favour of the commons we need instead to develop processes of law, co-operation and imagination, while working with the structures of representative democracy. The commoner is someone who seeks through a variety of material and symbolic means to open our horizons to a more generous view of the future fit for global humanity. The future of the commons depends on an educated and informed citizenry to produce a more decentralised and ecologically sensitive society. Considered in more performative terms the commoner works through the codes of 'civic purity and impurity' (Alexander 2011: 100). Like the Occupy movement it seeks to reveal the opposition between a hierarchical system that mostly benefits the global business class and everyone else. The problem with this argument is of course that there are a number of other complex divisions within the $99 \%$ that this view obscures. However it continues to point to the idea of common needs that are not met by a system that privileges the already very wealthy and powerful. The binary opposition between the needs of the people as opposed to the corruptions of capitalism is of course something that has a long and powerful history within socialist thought and thinking. Indeed Judith Butler (1997:50) has argued that in looking at the histories of discursive ideas and utterances we need to consider how the power of certain ideas and distinctions can be built up over time, removing any idea of the supposed sovereignty of individual authors. Here I want to explore the work of William Morris in relation to that of Raymond Williams.

\section{William Morris and the Idea of the Commons}

While previous waves of critique have sought to abandon Morris's work due to its perceived backward-looking medievalism, I suggest it remains an important if ambivalent touch-stone. More generous readings of Morris have suggested that his 
Romantic Marxism offers a critical break from scientific understandings of socialism (like that found within Althusserianism and rational choice Marxism) for a discussion of morality, the value of art and utopianism (Thompson 1994). E.P.Thompson (2014a, 2014b) who, despite differences with Williams shared a commitment to a humanist Marxism, argued that Morris remained a considerable influence for all those seeking to find a route between Leninist Marxism and social democracy. For Williams $(1958 ; 159)$ Morris's legacy was often 'diluted' through the erasure of his more politically radical work and the neglect of his attempt to link questions of art to ideas of the quality of our shared life in common. Morris is significant however for the way he opens up a more radical understanding of the commons. According to Peter Linebaugh (2014:110), the commons that pre-existed capitalism could be used to imagine the life of the commoner of the future. In William Morris's (1993) novel 'News from Nowhere' it is as if the society of the future had returned to the shared common land of the past without the ugly corruption, pollution and poverty of capitalism. Elsewhere Morris (1973a) suggests that socialism rejects a society built upon inequality and exploitation which is governed from above by masters and employers. Socialism offers the view that economic capital is not the same as the commonwealth. Here, as Morris himself recognised, he comes close to the critique of capitalist instrumentalism offered by other Romantic figures such as Ruskin. Ruskin (1985) had been critical of writers within the political economy tradition such as Ricardo for promoting the idea that material possessions and money mattered more than a concern for community, art and humanity. Morris however radicalised this view beyond the reformist visions of the socialism of the time. Ruth Kinna (2000) argues that Morris protested against two forms of oppression that can be related to capitalism. The first was that the resources necessary for human development were unequally distributed, and the other was the sheer waste and ugliness of capitalism that produced luxuries for the few and shoddy goods for the many. Morris (1973b:136) argues that socialists need to concern themselves not only with resources, but to ensure that all members of the community have the 'capacities for living a dignified and generous life'. Capitalism 'keeps us sweating and terrified for our livelihood', imposing a 'slavish life' on the majority while reserving a life of pleasure and luxury for the few (Morris 1973b:141). The socialist community yet to come would be built upon freedom, creativity and craft, beauty and the need to form reciprocal relationships with others. Art had a special role in William Morris's (1962a:139) vision as he asserted 'what business have we art unless all can share it'. This was not just the practice of sharing the visions of those people called artists, but more radically questioning the division of labour within society that relegated many to unskilled and uncreative labour. For Morris (1962b) art had a libidinous and hopeful energy that called into question the cruelty and exploitation of capitalism more generally. A more abundant life, captured by artistic forms of expression, calls into question the present whereby much culture is either produced explicitly for profit or expresses alienation.

The life of the commons imagined by Morris also has a marked similarity to much contemporary ecological writing. Richard Heinberg (2011) argues that in the context of peak oil, climate change and the dysfunctional economic system there is a need to break with the economic model of the past. This means that human beings need to be able to distribute resources more equally while moving the emphasis of our society away from wasteful consumerism towards the practice of making communities and engaging in more artistic forms of creativity. Similarly Juliet B. Schor (2011) argues that after the market crash of 2008 there is an opportunity to shift 
the debate away from a world of increasing marketisation, growth and profits to one that defines wealth in a different way. This would mean a new form of citizenship that seeks to build upon the common wealth we already share by reducing time at work; emphasising slower living patterns; ensuring more common resources that are free and publically available; consuming less, thereby reducing the size of our ecological footprint. This would provide new possibilities for more artisan forms of production, artistic forms of endeavor and more communal, face-to-face relationships.

Williams (1989a) similarly identifies the connections between socialism, ecology and the writing of William Morris, arguing that ecological ideas that simply point to environmental degradation without also connecting these concerns to the economic system are limited. Poverty and inequality can-not be cured within capitalism so ecological damage has to be linked to an understanding of the system. William Morris's critique of the destructiveness and over-consumption of shared resources caused by capitalism remains important in this respect. However Morris's writing does contain an important delusion in the suggestion that a more sustainable future can be created by returning to the simplicity of a life of peasants and craftsmen. For Williams (1989a) the society of the commons would be far more complex than life under neoliberal capitalism. Williams's (1979:128) point is that our visions of the future need to embrace more complex versions of the life of the commons, that do not become anti-technological or indeed fail to recognise cultural diversity. These crucial distinctions are especially significant for the performativity of art works, which after modernism, are unlikely to work within the ethical definitions set by Morris. Missing is modernism's anatagonism to Romanticism's medievalism and that the art of the future will require more militant and discordant features than those exhibited by the past (Hatherley 2008). Indeed as Tony Pinkney (1989:31) points out it was Williams's own modernism that led him to reject the lack of complexity and internal dissonance of Morris's vision.

These revisions in terms of the overall argument are especially important. If Williams remains connected to an ethical form of Marxism that opposes the idea of culture to that of the corruptions of the economy he does so by revising some of the main assumptions of the tradition within which he remains embedded. If part of the compelling story Williams wishes to tell is about the corruptions of capitalism he remains concerned with a vision of socialism that is overly simplistic and antimodern. The cultural revolution that Williams (1980a:267) hoped for would entail a redefinition of what we mean by economic and productive activity. In other words, the first artistic priority would be to reimagine the definitions of 'reality' imposed upon us by capitalism. This would inevitably mean that we talk about the limits to capitalist accumulation and the consumer model, given the limiting forms of class hierarchy and ecological devastation it brings in its wake, and think about how more areas of society can be directly self-managed. The break with the hierarchical logic of capitalism should also introduce questions of human need beyond the cash nexus. Such a perspective refuses an idea of 'human nature' that is defined by the existing consumer society. For William Morris (1973a) the common wealth of society offered a different understanding of human capacities. This clearly included the capacity to be creative rather than simply be subjected to the mechanised routines and disciplines of the factory, but equally it was to hold out for a different vision for humanity that included the possibilities of peaceful co-operation that struggled to find expression under capitalism. This remains an important argument within a culture that regularly reinforces an 'essentialist' understanding of human nature that matches the neoliberal assumptions that humans are competitive, aggressive and selfish. Following Hardt and 
Negri (2009:191) the point is less whether human nature is good or evil, but 'what human nature can become'. A more disordered view of society less governed by the rule of private property, might be able to give expression to other ways of being human that currently seem to be imaginatively off limits.

\section{The Culture of the Commons.}

From these reflections it follows that commoners will need to understand notions of culture in specific ways. Raymond Williams (1989b, 1989c) was especially keen to develop a model of culture that broke with the hierarchical arrangements of the dominant class society. Firstly there were a number of assumptions often made by intellectuals that the masses were somehow unfit for the appreciation of complex works of art and culture, and were unlikely to produce anything of value themselves. Secondly the private ownership of the means of production inevitably shaped modern society in terms of class relationships - these could only be progressively democratised when the economy was brought under a system of common ownership alongside more decentralised and self-managed forms of cultural and artistic production. These twin patterns of domination reinforced one another in practice. The argument that a meaningful culture could never be extended beyond the borders of an elite was reinforced by the argument that much (although not all) popular culture was of low cultural value. At this point in the argument Williams (1989b) proposes that much so-called popular culture is actually the culture of capitalism and the market rather than the culture of the people. Williams was consistently critical of not only the resources taken up by advertising that could conceivably be used to meet other human needs like education, but also how it defined citizens as consumers. Williams's (1989c:34) main argument was that we should resist the understanding of 'culture' as something produced by a special group of people called artists. Without doubting that the idea of culture was strongly connected to ideas of creativity this should be linked to the commons rather than a special professional class. For Williams (1989c:34-35) 'creation should not be reserved to a minority, however gifted'. Culture was never the creation of isolated figures disconnected from the life of the community, but was more often conceived in the context of a broader more collective experience. Here Williams takes aim at the idea of the 'Romantic myth' of the isolated artistic genius. Much of Williams's own work on dramatists and other artists sought to critique this model of culture that he perceived picked up on fairly widespread (and in this case harmful) forms of understanding. Williams's (1980c) essay on the Bloomsbury group makes this point by relating the intellectually diverse circle of this group to their historical and social context. Williams (1980c:165) argues that in this setting the group found some level of coherence around what he terms as "the supreme value of the civilized individual'. Williams then goes on in characteristic fashion to argue that this is an ideological construction that works through ideas of elites and masses that most of his critical work sought to question. However the broader point is that these attributes can be related back to the context of a hierarchical and capitalist-driven society at a particular point in history.

If cultural meanings and values can be related back to different social and historical contexts there is already a sense if contributions of culture belonging to the commons. To move beyond the commercial imperatives of the market and the elitist distinctions of a class society we have a responsibility to construct more democratic visions of culture. In this respect, Williams (1980c: 34) sometimes prefers the idea of a 'culture in common' to a common culture. If the creation of meaning is something 
citizens are engaged in - and if - artists are not a group of people who can be understood to be somehow 'outside' of these definitions - then a culture in common is the attempt to move beyond elite definitions and practices. As Williams (1980c:35) continues, 'one is bound to be shocked by any society which in its most explicit culture either suppresses the meanings and values of whole groups, or which fails to extend to these groups the possibility of articulating and communicating those meanings'. The culture in common is the democratic possibility of different members of society making a critical contribution to a range of experiences that are respected by a wider community.

Williams (1965) describes the processes by which the shared 'culture in common' becomes democratised as the long revolution. Here Williams seeks to understand the possibility of a shared educated and participatory democracy. These features were of course held in check by the commercial culture of the market and the class-related ideas and assumptions that can be associated with the need to maintain the hierarchical nature of capitalism. The long revolution becomes possible once we remember that 'the democratic revolution is still at a very early stage' (Williams 1965:10). Williams maintains a sense of a civic culture being developed by a society where previously excluded voices (the working-class, women, ethnic minorities) not only contribute to the 'culture in common', but also redefine as they do so what is meant by culture. In this respect, the long revolution is a complex and ongoing process. Williams (1989c:35) writes that 'I do not think that there is any possibility of a common culture, as I mean it, coming about simply by an act of extension of the minority'. Instead what is required is a break from the pattern of simply sorting and grading in the education system to a process where what could be more accurately described as 'the general 'recovery' of specifically alienated human capacities' (Williams 1980d:62). This recovery of the capacity to give voice to experience is likely to be an uneven and permanently unfinished process, given the often classed set of practices that privileges the experience of dominant groups. Of course such features are not only about the politics of class, but are also deeply implicated in the politics of race, gender and other forms of stratification. For Williams (1980d:57) the division of labour within advanced capitalist societies (the continued emphasis upon mental and manual labour) often meant that many working class people had poor written and literary skills. This meant that any socialist cultural strategy would need to develop the artistic and communicative capacities of the people beyond those required for the functioning of the economic system.

Other critics like Lewis Hyde (2010) and David Bollier (2005) have emphasised how the global stock of culture belongs to a shared humanity. Our common inheritance includes a diversity of cultures and traditions from across the planet that should be available to all. This is not to argue that the commons is without contestation, compassion, grief and marginalisation. For the commons to become genuinely democratic it needs to promote the possibility of a diversity of voices being exercised across a number of social and cultural divisions. For Williams this should be done carefully and respectfully. Indeed, despite some similarities that Williams shared with more anarchist cultural critics like Herbert Read (1963/2002) concerning the need to create more democratic forms of cultural production, he would have found himself out of sympathy with an approach that simply said 'to hell with culture' and called for a radical break with the past. If Williams agreed with Read that creativity should not be the special preserve of the artist he did not think that the so-called 'dead weight' of the past should be removed to allow for the spontaneous creative expression of the people. Instead Williams sought to both recognise the cultural 
presence of critical traditions within art and culture while seeking to provide creative openings for new forms of expression, especially amongst those who had been previously excluded.

Missing, however, in some versions of the idea of the commons is the way that the economic system and the hierarchical society more generally can impose silence upon some of its members. If the commons is threatened by enclosures through the use of intellectual copyright or pay walls then Williams's argument is that it is equally threatened by class and other forms of oppression. Williams's contribution to the idea of the commons is not only that as art and culture are democratised they will become more complex, but that they will need to address some of the more stubborn features of a class-based society. If the commons is what we share equally then we need to be concerned about who gets to participate in this process and who does not. For Williams (1980e:43) more democratic definitions of art and cultural practice have to recognise that no dominant culture 'in reality exhausts the full range of human practice, human energy, human intention'. This is because in a capitalist society certain forms of cultural and artistic production are cannot be turned into a profit. In this respect, the socialist project that seeks to recover the critical and creative capacity of the vast majority of people is not only likely to be complex, but also deeply painful as people learn to see themselves differently and potentially refashion their identities.

If anything Williams's writing sometimes seems to downplay these more difficult aspects of human recovery. Indeed, as we shall see later, it is probably true to argue that 'personal' features of cultural experience are more likely to appear in some of Williams's novels. As Valerie Walkerdine (1997) observes, much of the pain of working-class experience is missing from more 'objectivist' accounts of our shared understandings of culture. Indeed, despite Williams's fairly optimistic formulations, working class identities are likely to be deeply divided on many of the questions that Williams proposes. The histories of literally learning to labour and the instrumentalism of a governing culture urging people to 'get a job' and 'not become dependent upon welfare' might only with some difficulty be given up and questioned. Neoliberalism offers a limited repertoire in terms of what is meant by success. However Williams's writing often returns to the 'recitation' of certain class codes of reference that opposes the dignity of the working class that 'potentially' stands to be corrupted by the less than reliable middle classes (Lloyd 1999). These features are especially evident in Williams's (1989) novel 'Loyalties' where the working-class painter Nesta is seen to struggle for her creativity in ways most of the middle-class people who populate the novel seem to be unaware of. Williams also makes it clear that the working-class have an invested interest in socialism that becomes more complex (and sometimes corrupting) when supported by people who are not in the same structural position. Overall it is the dignity of the class most exploited and excluded by the workings of capital that takes centre stage in Williams's own writing. For Williams the dignity of the working class emerges not only through their own cultural resources, which remain under-realised within the present, but through their continued ability to resist capital and propose alternatives. 


\section{The Poetics of the Commons and Cultural Policy}

These questions then have implications not only for how we understand questions of culture and class-based forms of experience, but also link to questions of cultural policy. The cultural policy of the New Labour era can be credited with increased spending on the arts, building new venues and the removal of entrance prices to museums. However this was also accompanied by an increased instrumentality to produce measurable outcomes, centralise control and enhanced forms of managerialism. If, as Robert Hewison (2014:227) argues, we recognise art as contributing to the cultural commons, this should be built on everyone's right to participate. It is a basic human right to participate in the cultural life of the community as a civic actor rather than as simply a consumer. In this respect, Hewison $(2014 ; 228)$ argues that art needs to abandon what he calls the deficit model (where what receives support are areas unlikely to be supported by the market) for a model that places value upon the need to preserve cultural resources and create meaning and broader forms of public participation.

However, missing from the discussion so far is the role that Williams felt art should play within a more ecologically based society. Here we will need to look more closely at his novels, where he explicitly seeks to recover more place-based identities and a deeper sensitivity towards the locality and landscape. Williams's novels (1989d:117) also offer a critique of what he describes as a form of 'imperialism' based upon market individualism, disconnection and hostility to locality. The novels (that are often neglected by more sociological understandings of his writing) offer a critique of a form of instrumentalism and detachment from more local experiences and connections. This is a reccurring theme for Williams and is evident within his early and late work. In the semi-autobiographical novel Border Country Williams (1988a:9) describes how Matthew Price (an economic historian) who was working on population movements had lapsed into viewing people with 'the precision of icecubes'. Later in the novel Matthew (who has returned home to rural Wales) is alerted to the idea that more meaningful forms of reciprocity and community exist than seems to be possible within metropolitan centres like London. While Williams (1989d:115) is careful not to romanticise the level of social obligation that can exist within local communities he is clear that the erosion of more humanistic personal relationships has indeed been 'a grave loss'. The everyday world of mutual aid and neighbourhood obligation is undermined in a world of capitalistic 'mobile privativism' (Williams 1983:188). Here Williams argued that the increasing tendency of individuals and families to become detached from communities, and seen as economic units that can be moved through space and time, had a detrimental effect on the life of the community. Similarly more recent work has suggested that modern citizens live increasingly mobile and technological lives maintaining a 'distance' from being identified with specific localities (Elliott and Urry 2010). Technological capitalism has progressively organised society to increase hours spent at work, occupational stress and mental ill health while simultaneously eroding deeper attachments to the community (Berardi 2015). Under technological capitalism growing numbers of people are leading hurried, frenetic and pressured lives or experiencing exclusion. Not surprisingly then, much of the art related to the idea of the commons has involved the recovery of place and identity. For Williams (1989:242) place becomes significant as a location of solidarity with others. The working-class are less an international movement against capital than people who are often strongly connected to a specific 
locality. Williams is not unique in this observation, but it is critical within the context of a broader ecological politics that seeks to recover more complex and localised social relationships. This theme is also the central focus of Williams's $(1990,1992)$ late writing, found in what are often referred to as the 'Black Mountain' novels. Williams seeks to imaginatively recreate the lives of the Welsh people who lived on the mountains from the Ice Age and up to the Northern Conquest. The reason for doing this was often dismissed as a form of cultural nationalism, but for Williams it had a more profound significance. If, to return to a previous discussion, the socialism of the future was likely to be more complex than capitalism, this will be because of both its decentralised nature and because of the rediscovery of a sense of connection to local traditions and landscapes. Williams (1988b) argues that in writing these novels he sought to make a specific political intervention. For Williams (1988b:262) the 'only living connections are the physical presence of the mountains in which and under which so many different kinds of life have been lived, and the physical inheritors of these lives, who are not historically aware of them, whose memories are recent and whose projections, beyond those memories, are usually (not through their fault; it is what has passed for education) vague and wrong'.

The art of the commons will need to work against two kinds of enclosure. The first is where our arts venues and galleries - simply through corporate sponsorship or other means - are bent to the priorities of capital. More profoundly the art of the commons will also need to offer different understandings of our connections to locality and the natural world. For example, Rebbecca Martusewitz (2005) argues that the deindustrialisation of Detroit has been met by a number of social movements and educational initiatives that sought to build a politics out of a sense of place. The growing of food to be shared within the locality has emerged in the context of desperate need and the flight of capital. However it is also a means of resistance against the dominant culture of individualism, separation and control for a poetics of place. The development of mutual aid and reciprocity within poorer communities as opposed to the dehumanisation involved in the relocation of capital is something Williams would have recognised. Yet in addition, Williams is also reminding us that the politics of the commons is as much about the politics of the imagination as it is about new social and material relationships with ourselves and nature.

\section{Intellectuals and the Commons}

If intellectuals are significant for their ability to offer compelling accounts of the social world, as Raymond Williams demonstrates they can also be complex. The performativity of Williams's writing can be located not only in his ability to work on an opposition between the corruptions of capitalism and the humanistic potential of the working class, but also on his ability to connect these visions to critical social movements. This is not only a performative view of the intellectual, but a structural and materialist one as well. As Edward Said (1994:8) argues, all powerful social movements need intellectuals, but we should be careful of the compulsion to romanticise their role. If the role of the intellectual is to give voice to sometimes unpopular ideas they need to be careful they do not become trapped in formulas. Yet Williams can criticise the dominant capitalist society while building a complex and compelling account of socialism. As Williams (1989d:117) argued we live in a culture 'where parts of your mind are taken over by a system of ideas, a system of feelings, which really do emanate from the power centre'. To challenge this would require multivarious forms of 'commitment' that reject our corporate dominated world and 
the illusion of the disconnected self (Williams 1989h). In making these intellectual moves, Williams's writing obtains a performativity often missing elsewhere due to his ability to close the gap between the need to take a principled position within public debates while opposing the indifference of market-based capitalism. Writing in defence of Robert Tressell's (2001) great working-class novel, Williams (1988b:256) is able to defend the conventions of realism both through how it can connect to the experiences of generations of working-class readers and for its pedagogic ability to educate its audiences on the continued need to break out of the capitalist prison. The intellectual strategy at the heart of Williams's writing was to performatively contrast the instrumentality of capitalism with the more disruptive sensibility of artists such as himself and Tressell who explored the uncertain connections between themselves, place and the lived relations of a class based society. The division between complexities of culture and the often crude operations of the markets lies at the heart of his intellectual endeavour. If Jeffrey Alexander (2006:550) remains concerned by the extent to which the oppositions of Marxism offers a 'big bang' theory of social change then this could not be said of Williams. His commitment to the intricacies of what he often refered to as the 'long revolution' means he is likely to be returned to by scholars and activists now and in the future searching for complex humane alternatives to capitalism. 


\section{Bibliography}

Alexander, J.C. (2003) The Meanings of Social Life, Oxford, Oxford University Press.

Alexander, J.C. (2006) The Civil Sphere, Oxford, Oxford University Press.

Alexander, J.C. (2011) Performance and Power, Cambridge, Polity Press.

Alexander, J.C. (2016) 'Dramatic Intellectuals', Int J Cult Soc 29 pp341-358.

Anderson, P. (1976) Considerations on Western Marxism, London, Verso.

Bauman, Z. (1992) Intimations of Postmodernity, London, Routledge.

Beart, P. (2015) The Existential Moment: The Rise of Sartre as a Public Intellectual, Cambridge, Polity Press.

Berardi, F.B. (2015) Heroes: Mass Murder and Suicide, London, Verso.

Bollier, D. (2005) Brand Name Bullies, New Jersey, John Wiley and Sons Inc.

Bollier, D. (2014) Think Like A Commoner, Gabriola islands, New Society,

Publishers.

Butler, J. (1997) Excitable Speech: A Politics of the Performative, London,

Routledge.

Eagleton, T. (2011) Why Marx Was Right, New Haven and London, Yale University

Press.

Furedi, F. (2004) Where Have All The Intellectuals Gone?, London, Continuum.

Giroux, H. (2007) 'Cultural Studies as Performative Practice' in Denzin, D.K. and

Giardina, M.D. (eds) Contesting Empire, London, Taylor and Francis.

Giroux, H. (2011) On Critical Pedagogy, London, Continuum.

Gramsci, A. (1988) 'Intellectuals and Education', A Gramsci Reader, Lonson,

Lawerence and Wishart pp300-322.

Hardt, M. and Negri, A. (2009) Commonwealth, Cambridge, Harvard University

Press.

Harvey, D. (2012) Rebel Cities, London, Verso.

Hatherley, O. (2008) Militant Modernism, London, Zero Books.

Heinberg, R. (2011) The End of Growth, Gabriola Island, New Society Publishers.

Hewison, R. (2014) Cultural Capital: The Rise and Fall of Creative Britain, London, Verso.

Hyde, L. (2010) Common As Air: Revolution, Art and Ownership, New York, Straus and Giroux.

Kinna, R. (2000) William Morris: the art of socialism, Cardiff, University of Wales.

Linebaugh, P. (2014) Stop, Thief! The Commons, Enclosures and Resistance,

Oakland, PM Press.

Lloyd, M. (1999) 'Performativity, Parody, Politics', in Bell, V. (ed) Performativity and Belonging, London, Sage pp195-214.

Misztal, B. (2012) 'Public Intellectuals and Think Tanks: A Free Market In Ideas', Int J Polit Cult Soc 25 pp127-141.

Martusewicz, R. (2005) 'Eros in the Commons: Educating for Eco-ethical

Consciousness in a Poetics of Place', Ethics, Place and Environment 8(3) pp331-348. 
Morris, W. (1962a) 'Art and Society: Letter to Manchester Exainer, 14 March 1883', in Briggs, A. (ed) William Morris: Selected Writings and Designs, London Penguin Books pp139-140.

Morris, W. (1962b) 'The Workers Share of Art: From an article in Commonweal, April 1885' in Briggs, A. (ed) William Morris: Selected Writings and Designs, London Penguin Books pp140-142.

Morris, W. (1973a) 'How I Became A Socialist', in Morton, A.L. ed (1973) Political Writings of William Morris, London, Lawerence and Wishart pp241-246.

Morris, W. (1973b) 'How We Live and How We Might Live', in Morton, A.L. ed (1973) Political Writings of William Morris, London, Lawerence and Wishart pp134158.

Morris, W. (1973c) 'The Society of the Future', in Morton, A.L. ed (1973) Political Writings of William Morris, London, Lawerence and Wishart pp188-204.

Morris, W. (2013) News from Nowhere and Other Writings, London, Penguin Classics.

Pinkney, T. (1989) 'Williams and the 'Two Faces of Modernism', in Eagelton, T. (ed) Raymond Williams: Critical Perspectives, Cambridge, Polity Press pp12-33. Read, H. (1963/2002) To Hell With Culture, London, Routledge.

Ruskin, J. (1985) Unto This Last and Other Writings, London, Penguin.

Said, E. (1994) Representations of the Intellectual, London, Vintage.

Schor, J.B. (2011) True Wealth, London, Penguin.

Thompson, E.P. (1994) 'William Morris', in Making History: Writings on History and Culture, London, Merlin pp66-77.

Thomson, E.P. (2014a) 'The Long Revolution', in Winslow, C (ed) E.P.Thompson and the Making of the New Left, New York and London, Monthly Review pp187214.

Thompson, E.P. (2014b) 'Socialist Humanism', in Winslow, C (ed) E.P.Thompson and the Making of the New Left, New York and London, Monthly Review pp89-102. Tressell, R. (2001) The Ragged Trousered Philanthropists, Oxford, Oxford University Press.

Walkerdine, V. (1997) Daddy's Girl: Young Girls and Popular Culture, Basingstoke, MacMillan Press.

Williams, R. (1958) Culture and Society 1780-1950, London, Penguin Books.

Williams, R. (1965) The Long Revolution, London, Pelican books.

Williams, R. (1979) Politics and Letters: Interviews with New Left Review, London, Verso.

Williams, R. (1980a) 'Beyond actually Existing Socialism', in Culture and

Materialism, London, Verso pp252-274.

Williams, R. (1980b) ‘Advertising: the Magic System', in Culture and Materialism, London, Verso pp170-195.

Williams, R. (1980c) ‘The Bloomsbury Fraction', in Culture and Materialism, London, Verso pp170-195.

Williams, R. (1980d) 'Means of Communication as Means of Production', in Culture and Materialism, London, Verso pp50-63.

Williams, R. (1980e) 'Base and Superstructure in Marxist Cultural Theory', in

Culture and Materialism, London, Verso pp31-49.

Williams, R. (1981) Culture, London, Fontana.

Williams, R. (1983) Towards 2000, London, Chatto and Windus.

Williams, R. (1988a) Border Country, London, Hogarth Press.

Williams, R. (1988b) Writing in Society, London, Verso. 
Williams, R. (1989) Loyalities, London, The Hogarth Press.

Williams, R. (1989a) 'Socialism and Ecology', in Resources of Hope, London, Verso pp210-226.

Williams, R. (1989b) 'Culture is Ordinary', in Resources of Hope, London, Verso pp3-18.

Williams, R. (1989c) 'The Idea of a Common Culture', in Resources of Hope, London, Verso pp32-38.

Williams, R. (1989d) 'The Importance of Community', in Resources of Hope, London, Verso pp151-160.

Williams, R. (1989e) 'Decentralism and the Politics of Place', In Resources of Hope, London, Verso pp238-244.

Williams, R. (1989h) 'The Writer: Commitment and Alignment', in Resources of Hope, London, Verso pp77-87. ,

Williams, R. (1990) People of the Black Mountains; 1 The Beginning, London, Paladin.

Williams, R. (1992) People of the Black Mountains; 2 The Eggs and the Eagle, London, Paladin. 